\title{
KONDISI TERKINI PENYAKIT KUSTA \\ DI WILAYAH KERJA DINAS KESEHATAN KABUPATEN GOWA
}

\section{LATEST CONDITIONS OF LEPROSY DISEASE IN THE WORKING AREA OF HEALTH OFFICE OF GOWA DISTRICT}

\author{
Wibowo', Amir Su'udi ${ }^{1}$, Muh.Sahir ${ }^{2}$ \\ 1. Pusat Penelitian Dan Pengembangan Sumber Daya dan Pelayanan Kesehatan \\ Badan Penelitian Dan Pengembangan Kesehatan,Kementerian Kesehatan RI,Jakarta \\ 2. Dinas Kesehatan Kabupaten Gowa Provinsi Sulawesi Selatan.
}

Koresponden : wibow0869@yahoo.co.id

\begin{abstract}
ABSTRAK
Penyakit lepra, yang lebih dikenal dengan Morbus Hansen atau kusta adalah infeksi kulit kronis yang disebabkan oleh bakteri Mycobacterium leprae. Lepra termasuk penyakit tertua dalam sejarah, dikenal sejak tahun 1400 sebelum masehi. Infeksi ini menyerang saraf tepi dan kulit, kemudian saluran pernapasan atas, dan bisa juga menyerang organ lain kecuali otak. Jumlah penderita lepra di dunia pada tahun 2007 diperkirakan 2-3 juta orang lebih. Pada 2008, penderita penyakit lepra di Indonesia diperkirakan sebanyak 22.359 atau 0,73 kasus dari setiap 100.000 penduduk, dengan jumlah kasus baru sebanyak 16.668. Penyakit ini banyak ditemukan terutama di pulau Jawa, Sulawesi, Maluku, dan Papua. Tujuan penelitian ini adalah untuk mendapatkan gambaran situasi terkini penyakit kusta di wilayah kerja dinas kesehatan kabupaten Gowa Sulawesi Selatan. Hasil penelitian ditemukan adanya kasus kusta di wilayah kerja dinas kesehatan Kabupaten Gowa Sulawesi Selatan diketahui bahwa penemuan kasus kusta tertinggi adalah Pausi Basiler sebesar 56,3\% pada laki-laki dan sebesar 43,7\% ditemukan pada perempuan. Sedangkan kasus tertinggi pada kusta Multi Basiler adalah sebesar $69,1 \%$ pada laki-laki dan sebesar 30,9\% ditemukan pada perempuan. Berdasarkan tabel di atas dapat diketahui bahwa penemuan kasus kusta pausi basiler tertinggi di wilayah Kabupaten Gowa adalah sebesar 37,5\% yang terdapat di Kecamatan Sombaopu dan penemuan kasus terendah adalah sebesar 6,25\% di Kecamatan Kanjilo dan Parangloe. Sedangkan penemuan kasus kusta multi basiler tertinggi di wilayah Kabupaten Gowa adalah sebesar 17,3\% yang terdapat di Kecamatan Tompobulu dan penemuan kasus terendah adalah sebesar 1,2\% di Kecamatan Bungaya. Kesimpulan : ditemukan kasus kusta di wilayah kerja dinas kesehatan kabupaten Gowa Sulawesi Selatan.
\end{abstract}

Kata kunci : Mycobacterium leprae, kasus kusta di dinas kesehatan kabupaten Gowa

\section{ABSTRACT}

Leprosy, better known as Morbus Hansen or leprosy is a chronic skin infection caused by the bacterium Mycobacterium leprae. Leprosy is one of the oldest diseases in history, known since 1400 BC. This infection attacks the peripheral nerves and skin, then the upper respiratory tract, and can also attack other organs except the brain. The number of people with leprosy in the world in 2007 was estimated at more than 2-3 million people. In 2008, people with leprosy in Indonesia were estimated at 22,359 or 0.73 cases out of every 100,000 population, with the number of new cases as many as 16,668. This disease is found mainly in the islands of Java, Sulawesi, Maluku and Papua. The purpose of this study was to obtain an overview of the current situation of leprosy in the working area of the health office of Gowa district, South Sulawesi. The results of the study found that there were cases of leprosy in the working area of the Gowa District health office in South Sulawesi. It was found that the highest leprosy case finding was Pausi Basiler at $56.3 \%$ in men and $43.7 \%$ in women. While the highest cases in Multi Basiler leprosy were $69.1 \%$ in men and $30.9 \%$ were found in women. Based on the table above, it can be seen that the highest cases of bacillary paustic cases in Gowa Regency were $37.5 \%$ in Sombaopu Subdistrict and the lowest case findings were $6.25 \%$ in Kanjilo and Parangloe Subdistricts. Whereas the highest number of cases of multi-bacillary leprosy in Gowa Regency was $17.3 \%$ in Tompobulu Subdistrict and the lowest case finding was 1.2\% in Bungaya District. Conclusion: Leprosy cases were found in the working area of the health office in Gowa district, South Sulawesi.

Keywords: Mycobacterium leprae, leprosy case in the Gowa district health office

Vol. XIV No. 1, Juni 2019

DOI: https://doi.org/10.32382/medkes.v14i1.924 


\section{PENDAHULUAN}

Kusta masih merupakan masalah kesehatan di Indonesia. Salah satunya adalah penyakit ini ditakuti dapat menyebabkan kecacatan permanen, mutilasi (misalnya terputusnya salah satu anggota gerak seperti jari), ulserasi (luka borok). Infeksi kulit ini disebabkan karena adanya kerusakan saraf besar di daerah wajah, anggota gerak, dan motorik; diikuti dengan rasa baal yang disertai kelumpuhan otot dan pengecilan massa otot Penyakit Kusta atau lepra merupakan penyakit menular yang disebabkan oleh infeksi bakteri Mycrobacterium leprae. Penyakit kusta ini memiliki dua macam tipe gejala klinis yaitu pausibasilar (PB) dan multibasilar (MB). Kusta tipe PB adalah tipe kusta yang tidak menular, sedangkan kusta tipe $\mathrm{MB}$ adalah tipe kusta yang mudah menular. 1,2

Negara yang masih banyak ditemukan penyakit kusta adalah Somalia. Pada tahun 2015 ditemukan 107 pada tahun 2018 menjadi 2610. Dari 2610 kasus baru yang terdeteksi ada 1207 (46\%) adalah perempuan, $138(5 \%)$ adalah anak-anak dan $129(5 \%)$, termasuk tiga anak, menderita cacat sebagian disebabkan oleh perpindahan penduduk yang disebabkan oleh kekeringan dan kerusuhan sipil yang berkepanjangan, dan sejumlah besar telah menumpuk di kamp-kamp yang menampung para pengungsi ${ }^{3,4}$.

Faktor penyebab munculnya penularan kusta salah satunya adalah kebersihan dari lingkungan. Kondisi rumah dengan dinding yang terbuat dari kayu, papan, dan bambu akan menyebabkan penumpukan debu, sehingga dinding sulit untuk dibersihkan dan dapat menjadi media yang baik untuk perkembangbiakan bakteri termasuk bakteri Mycrobacterium leprae. Lengketnya debu di kayu akan menyebabkan lebih besar untuk terjadinya penyakit kusta karena adanya Mycrobacterium leprae pada debu tadi. Juga bisa terjadi Mycrobacterium leprae di air untuk mandi dan mencuci di rumah penderita. Harus diperhatikan kondisi lingkungan agar dapat mencegah penyebaran Mycrobacterium leprae di lingkungan tersebut ${ }^{5,6}$.
Mycrobacterium leprae juga dapat bertahan hidup ditanah hingga 46 hari. Kepadatan hunian juga menjadi faktor risiko penularan penyakit kusta, hal ini disebabkan karena penderita akan banyak kontak dengan non penderita sehingga akan menyebabkan menularnya penyakit kusta ke anggota keluarga yang lain. ${ }^{7,8,9}$

Menurut data Kementerian Kesehatan Republik Indonesia bahwa prevalensi penyakit kusta di dunia masih tinggi. World Health Organization (WHO) mencatat pada tahun 2014, sebanyak 213.899 penemuan kasus baru kusta terdeteksi di seluruh dunia dengan kasus tertinggi berada di regional Asia Tenggara yakni sebesar 154.834 kasus. Prevalensi kusta pada awal tahun 2015 didapatkan sebesar 0,31 per 100.000 penduduk. Indonesia menduduki peringkat ketiga negara dengan endemik kusta terbanyak setelah India dan Brazil. Kejadian Kusta masih sangat tinggi di beberapa negara, terutama negara berkembang yang sangat erat kaitannya dengan tingkat kemiskinan dan kepadatan penduduk. Studi epidemiologi di Cebu (Filiphina) mendapatkan sebanyak 3288 kasus kusta pada tahun 2000-2010, dengan penemuan terbanyak di daerah padat penduduk ${ }^{10,11,12}$

\section{METODE}

Penelitian ini adalah penelitian deskriftif dengan desain penelitian crosssectional untuk mendapatkan kondisi terkini dari penyakit kusta di wilayah kerja dinas kesehatan kabupaten Gowa Provinsi Sulawesi Selatan tahun 2017. Data penelitian menggunakan data sekunder yang diperoleh dari laporan bulanan kasus Kusta dinas kesehatan kabupaten Gowa Provinsi Sulawesi Selatan tahun 2017. Analisis data menggunakan Microsoft exel dengan analisis univariat. Sampel pada penelitian ini adalah kejadian penyakit kusta di 25 puskesmas dan 19 kecamatan di kabupaten Gowa.

\section{HASIL}

Penelitian ini menghasilkan lebih banyak responden yang berjenis kelamin laki-laki sebanyak $56,3 \%$ dan responden perempuan $43,7 \%$. (Tabel 1).

Tabel. 1.1 Distribusi Penemuan Kasus Kusta Berdasarkan Jenis Kelamin di wilayah Kabupaten Gowa Tahun 2017

Jenis Kelamin

Kusta Pausi Basiler
Kusta Multi Basiler

Vol. XIV No. 1, Juni 2019

DOI: https://doi.org/10.32382/medkes.v14i1.924 


\begin{tabular}{|c|c|c|c|c|}
\hline & $\mathrm{n}$ & $\%$ & $\mathrm{n}$ & $\%$ \\
\hline Laki-laki & 9 & 56,3 & 56 & 69,1 \\
\hline Perempuan & 7 & 43,7 & 25 & 30,9 \\
\hline Total & $\mathbf{1 6}$ & $\mathbf{1 0 0 , 0}$ & $\mathbf{8 1}$ & $\mathbf{1 0 0 , 0}$ \\
\hline
\end{tabular}

Berdasarkan tabel di atas dapat diketahui bahwa penemuan kasus kusta Pausi Basiler tertinggi di wilayah Kabupaten Gowa pada tahun 2017 adalah sebesar $56,3 \%$ pada laki-laki dan sebesar $43,7 \%$ ditemukan pada perempuan. Sedangkan kasus tertinggi pada kusta Multi Basiler adalah sebesar $69,1 \%$ pada laki-laki dan sebesar $30,9 \%$ ditemukan pada perempuan.

Tabel 1.2 Distribusi Penemuan Kasus Kusta Berdasarkan Kecamatan di wilayah Kabupaten Gowa Tahun 2017

\begin{tabular}{|l|c|c|c|c|}
\hline \multirow{2}{*}{ Kecamatan } & \multicolumn{2}{|c|}{ Kusta Pausi Basiler } & \multicolumn{2}{c|}{ Kusta Multi Basiler } \\
\cline { 2 - 5 } & $\mathrm{n}$ & $\%$ & $\mathrm{n}$ & $\%$ \\
\hline Sombaopu & 6 & 37,5 & 10 & 12,4 \\
\hline Pallangga & 0 & 0 & 6 & 7,4 \\
\hline Barombong & 0 & 0 & 0 & 0 \\
\hline Kanjilo & 1 & 6,25 & 0 & 0 \\
\hline Bajeng & 2 & 12,5 & 6 & 7,4 \\
\hline Bajeng Barat & 0 & 0 & 2 & 2,5 \\
\hline Bontonompo Selatan & 0 & 0 & 3 & 3,7 \\
\hline Bontonompo & 4 & 25 & 2 & 2,5 \\
\hline Bontomarannu & 0 & 0 & 2 & 2,5 \\
\hline Pattallassang & 0 & 0 & 3 & 3,7 \\
\hline Parangloe & 1 & 6,25 & 1 & 1,2 \\
\hline Manuju & 0 & 0 & 6 & 7,4 \\
\hline Tinggimoncong & 0 & 0 & 3 & 3,7 \\
\hline Parigi & 0 & 0 & 0 & 0 \\
\hline Tombolopao & 0 & 0 & 7 & 8,6 \\
\hline Tompobulu & 0 & 0 & 14 & 17,3 \\
\hline Biringbulu & 0 & 0 & 6 & 7,4 \\
\hline Bungaya & 0 & 0 & 1 & 1,2 \\
\hline Bontolempangan & 2 & 12,5 & 9 & 11,1 \\
\hline \multicolumn{1}{|c|}{ Total } & $\mathbf{1 6}$ & $\mathbf{1 0 0 , 0}$ & $\mathbf{8 1}$ & $\mathbf{1 0 0 , 0}$ \\
\hline
\end{tabular}

Berdasarkan tabel di atas dapat diketahui bahwa penemuan kasus kusta pausi basiler tertinggi di wilayah Kabupaten Gowa adalah sebesar $37,5 \%$ yang terdapat di Kecamatan Sombaopu dan penemuan kasus terendah adalah sebesar $6,25 \%$ di Kecamatan Kanjilo dan Parangloe.
Sedangkan penemuan kasus kusta multi basiler tertinggi di wilayah Kabupaten Gowa adalah sebesar $17,3 \%$ yang terdapat di Kecamatan Tompobulu dan penemuan kasus terendah adalah sebesar $1,2 \%$ di Kecamatan Bungaya.

Tabel 1.3 Distribusi Penemuan Kasus Pneumonia Balita Berdasarkan Puskesmas di wilayah Kabupaten Gowa Tahun 2017

\begin{tabular}{|l|c|c|c|c|}
\hline \multirow{2}{*}{ Puskesmas } & \multicolumn{2}{c|}{ Kusta Pausi Basiler } & \multicolumn{2}{c|}{ Kusta Multi Basiler } \\
\cline { 2 - 5 } & $\mathrm{n}$ & $\%$ & $\mathrm{n}$ & $\%$ \\
\hline Sombaopu & 6 & 37,5 & 9 & 11,1 \\
\hline Samata & 0 & 0 & 1 & 1,2 \\
\hline Pallangga & 0 & 0 & 5 & 6,2 \\
\hline Kampili & 0 & 0 & 1 & 1,2 \\
\hline Mancobalang & 0 & 0 & 0 & 0 \\
\hline Kanjilo & 1 & 6,25 & 0 & 0 \\
\hline
\end{tabular}




\begin{tabular}{|l|c|c|c|c|}
\hline Bajeng & 2 & 12,5 & 4 & 4,9 \\
\hline Pa'bentengan & 0 & 0 & 2 & 2,5 \\
\hline Gentungan & 0 & 0 & 2 & 2,5 \\
\hline Bontonompo I & 0 & 0 & 3 & 3,7 \\
\hline Bontonompo II & 4 & 25 & 2 & 2,5 \\
\hline Bontomarannu & 0 & 0 & 2 & 2,5 \\
\hline Pattallassang & 0 & 0 & 3 & 3,7 \\
\hline Paccelekang & 0 & 0 & 0 & 0 \\
\hline Parangloe & 1 & 6,25 & 1 & 1,2 \\
\hline Manuju & 0 & 0 & 6 & 7,4 \\
\hline Tinggimoncong & 0 & 0 & 3 & 3,7 \\
\hline Parigi & 0 & 0 & 0 & 0 \\
\hline Tamaona & 0 & 0 & 7 & 8,6 \\
\hline Tompobulu & 0 & 0 & 14 & $\mathbf{1 7 , 3}$ \\
\hline Tonrorita & 0 & 0 & 4 & 4,9 \\
\hline Lauwa & 0 & 0 & 2 & 2,5 \\
\hline Bontomalonro & 0 & 0 & 0 & 0 \\
\hline Sapaya & 0 & 0 & 1 & 1,2 \\
\hline Bt.Lempangan & 1 & 6,25 & 5 & 6,3 \\
\hline Bontolempangan II & 1 & 6,25 & 4 & 4,9 \\
\hline \multicolumn{1}{|c|}{ Total } & 16 & $\mathbf{1 0 0 , 0}$ & 81 & $\mathbf{1 0 0 , 0}$ \\
\hline
\end{tabular}

Berdasarkan tabel di atas dapat diketahui bahwa penemuan kasus kusta pausi basiler tertinggi di wilayah Kabupaten Gowa adalah sebesar $37,5 \%$ yang terdapat di Puskesmas Sombaopu dan penemuan kasus terendah adalah sebesar $6,25 \%$ di Puskesmas Kanjilo, Parangloe, Bt.Lempangan dan Bontolempangan II. Sedangkan penemuan kasus kusta multi basiler tertinggi di wilayah Kabupaten Gowa adalah sebesar $17,3 \%$ yang terdapat di Puskesmas Tompobulu dan penemuan kasus terendah adalah sebesar 1,2\% di Puskesmas Samata, Kampili, Parangloe dan Sapaya.

\section{PEMBAHASAN}

Pada penelitian ini, ditemukan adanya kasus kusta di wilayah kerja dinas kesehatan kabupaten Gowa Sulawesi Selatan diketahui bahwa penemuan kasus kusta tertinggi adalah Pausi Basiler sebesar $56,3 \%$ pada laki-laki dan sebesar $43,7 \%$ ditemukan pada perempuan. Sedangkan kasus tertinggi pada kusta Multi Basiler adalah sebesar $69,1 \%$ pada laki-laki dan sebesar $30,9 \%$ ditemukan pada perempuan. Berdasarkan tabel di atas dapat diketahui bahwa penemuan kasus kusta pausi basiler tertinggi di wilayah Kabupaten Gowa adalah sebesar $37,5 \%$ yang terdapat di Kecamatan Sombaopu dan penemuan kasus terendah adalah sebesar 6,25\% di Kecamatan Kanjilo dan Parangloe. Sedangkan penemuan kasus kusta multi basiler tertinggi di wilayah kabupaten Gowa adalah sebesar 17,3\% yang terdapat di kecamatan Tompobulu dan penemuan kasus terendah adalah sebesar $1,2 \%$ di kecamatan Bungaya.

Kondisi rumah yang sehat salah satunya dengan adanya ventilasi. Rumah dengan ventilasi yang sesuai dengan standar kesehatan sangatlah penting. Keberadaan ventilasi merupakan suatu syarat kesehatan yang bisa mengakibatkan terhalangnya proses pertukaran aliran udara dan sinar matahari yang masuk ke dalam rumah, sehingga semakin lembab rumah maka semakin besar kemungkinan perkembangbiakan mikroorganisme di dalam rumah. Mikroorganisme dapat berada di udara melalui berbagai cara terutama dari debu yang berterbangan. Perlunya ventilasi yang memenuhi standar kesehatan agar udara di dalam ruangan dapat bersirkulasi dengan baik secara terus menerus

\section{KESIMPULAN}

Hasil penelitian ini ditemukan adanya kasus kusta di wilayah kerja dinas kesehatan kabupaten Gowa Sulawesi Selatan diketahui bahwa penemuan kasus kusta tertinggi adalah Pausi Basiler sebesar $56,3 \%$ pada laki-laki dan sebesar $43,7 \%$ ditemukan pada perempuan. Sedangkan kasus tertinggi pada kusta Multi Basiler adalah sebesar $69,1 \%$ pada laki-laki dan sebesar $30,9 \%$ ditemukan pada perempuan. Berdasarkan tabel di atas dapat diketahui bahwa penemuan kasus kusta pausi basiler 
tertinggi di wilayah kabupaten Gowa adalah sebesar $37,5 \%$ yang terdapat di kecamatan Sombaopu dan penemuan kasus terendah adalah sebesar 6,25\% di kecamatan Kanjilo dan Parangloe. Sedangkan penemuan kasus kusta multi basiler tertinggi di wilayah kabupaten Gowa adalah sebesar 17,3\% yang terdapat di kecamatan Tompobulu dan penemuan kasus terendah adalah sebesar $1,2 \%$ di kecamatan Bungaya.

\section{UCAPAN TERIMAKASIH}

Penulis mengucapkan banyak terima kasih atas bantuan dari Dr. $\mathrm{H}$ Hasanuddin Kepala Dinkes Kesehtan Kabupaten Gowa, Kepala Badan Litbangkes Kemenkes dan Kepala Pusat Sumber Daya dan Pelayanan Kesehatan Kementrian Kesehatan Republik Indonesia yang telah memberikan kesempatan untuk melakukan penulisan artikel ini, dan terimakasih kepada bpk. DR Rudhi Hartono,SKM,MKes dari Poltekes Makassar dan ibu Husnul Khatimah, S.Kep,NS dari dinas kesehatan kabupaten Gowa. Terimkasih kepada semua pihak yang telah membantu sehingga penulisan artikel ini bisa dipublikasi dan berjalan lancar, aamiin

\section{DAFTAR PUSTAKA}

Widoyono. Penyakit Tropis Epidemiologi: Penularan, Pencegahan, dan Pemberantasannya Edisi Kedua. Jakarta: Erlangga;2011.

Awaluddin. Beberapa Faktor Risiko Kontak dengan Penderita Kusta dan Lingkungan yang Berpengaruh Terhadap Kejadian Kusta di Kabupaten Brebe [Tesis]. Semarang:

Faturahman, Yuldan. Faktor Lingkungan Fisik Rumah yang Berhubungan dengan Kejadian Kusta di Kabupaten
Cilacap. Jurnal FKM UNSIL. 2011; 282-295.

Amirudin, Muhammad Dali. Penyakit Kusta Sebuah Pendekatan Klinis. Makassar: Brilian International; 2012.

Universitas Diponegoro; 2004. World Health Organization. Prevalence of Leprosy. [diakses 18 januari 2014]. Available at:

http://www.who.int/lep/sotuation/prev alence/en/index.html.

Ditjen PP\&PL Kemenkes RI. Profil Kesehatan Indonesia 2011. Jakarta: Keenterian Kesehatan RI; 2012

Bidang P2PL Provinsi Sulawesi Selatan. Profil Kesehatan Sulawesi Selatan 2013. Dinas Kesehatan Sulawesi Selatan. 2014.

Norlatifah, Adi Heru Sutomo, Solikhah. Hubungan Kondisi Fisik Rumah, Sarana Air Bersih dan Karakteristik Masyarakat dengan Kejadian Kusta di Kabupaten Tapin Kalimantan Selatan. Jurnal Kesmas UAD. 2010; 4(3) 144 - 239.

Amirudin, Muhammad Dali. Penyakit Kusta Sebuah Pendekatan Klinis. Makassar: Brilian International; 2012.

Faturahman, Yuldan. Faktor Lingkungan Fisik Rumah yang Berhubungan dengan Kejadian Kusta di Kabupaten Cilacap. Jurnal FKM UNSIL. 2011; 282-295.

Rismayanti, Dwina. 2012. Hubungan Antara Sanitasi rumah dan Personal Hygiene dengan kejadian Kusta Multibasiler. Unnes Journal of Public Health. 2012; 1(2): $1-10$

Syamsir, Makmur Selamo, Erniwati Ibrahim. Karakteristik Kondisi Hunian Penderita Kusta di Wilayah Kerja Puskesmas Turikale dan Mandai Kabupaten Maros. Jurnal Kesmas UAD. 2012; 1 - 9. 